\title{
Preliminary data for melt inclusions in garnet porphyroblasts from Ograzhden metapelites, SW Bulgaria
}

\section{Предварителни данни за топилкови включения в гранатови порфиробласти от Огражденските метапелити, ЮЗ България}

\author{
Lyubomira Macheva \\ Любомира Мачева
}

\begin{abstract}
Institute of Mineralogy and Crystallography, Bulgarian Academy of Science, Acad. G. Bonchev Str., B1. 107, 1113 Sofia; E-mail: lu_macheva@dir.bg
\end{abstract}

Keywords: metamorphism, melt inclusions, metapelites, Ograzhden.

\section{Introduction}

Decoding the complicated evolution of the high grade metamorphosed crustal rocks is a big challenge. Furthermore, in most cases preserving of memory for the metamorphic events is difficult due to the large scale late-stage recrystallization and obliteration of suitable key minerals and mineral associations. Inclusions and exsolution microstructures in refractory minerals play in these circumstances an important role in recognition and characterization of the metamorphic evolution. Here we report our first results on the study of mono- and polyphase micro-inclusions, as well as exsolution microstructures in garnet from crustal rocks of the Bulgarian part of the Serbo-Macedonian Massif.

\section{Geological setting and field observations}

The studied rocks, cropping out in the most southeastern part of Bulgaria are traditionally referred to the Lower Ograzhdenian Complex (Vertiskos Unit in Greece) of the Serbo-Macedonian Massif. Recently, it is considered an allochthonous part of the Rhodope metamorphic complex (Ricou et al., 1998; Burg et al., 2012, etc), or an integral part of the Southern Carpathians (Schmid et al., 2020). Migmatised Ordovician in age porphyritic and equigranular metagranitoids as well as metabasites along with upper Proterozoic-lower Cambrian paragneisses, Al-rich metapelites and metaeclogites presently of unknown age constitute the high-grade metamorphic complex in the area. These rocks have undergone complicated metamorphic history changing from HP-UHP/HT, followed by HT-MP and finally LP/LT metamorphism.

High- and low aluminous metapelites, which are the topic of this study occurred as irregular elongated bodies SE of the village of Nikudin, west and SW of the village of Igralishte, and WSW of Lebnitsa. Small bodies can also be observed in Belasitsa Mountain ESE of Kolarovo.

\section{Mineralogical features of metapelites}

Typically, metapelites are coarse grained low aluminous (plagioclase-bearing) or high-aluminous in composition. Plagioclase-bearing schists exhibit mineral composition, usually represented by plagioclase, quartz, white mica, biotite, garnet, \pm staurolite, \pm tourmaline, \pm kyanite and accessory epidote, apatite, ilmenite, monazite, zircon and rutile, whereas the mineral assemblage of high-aluminous metapelites rarely contains plagioclase and consists of garnet, kyanite, fibrolitic sillimanite, white mica, quartz, staurolite, \pm chloritoid, \pm tourmaline, \pm plagioclase, biotite. Accessories are rutile, ilmenite, apatite and zircon. Chlorite is an alteration product of garnet and biotite in both types of metapelites. Based on microstructural position several generations garnet, staurolite, kyanite, biotite and white micas can be distinguished, which are described in more details elsewhere (e.g., Peytcheva et al., 2015), and which we will not deal with here, as the object of this study are the micro-inclusions in the garnet porphyroblasts, especially its first generation, that is coarse grained (up to $1.5-2 \mathrm{~cm}$ in diameter), subidioblastic or 
with corroded outlines, mostly strongly fractured and replaced by alteration products. Relatively well preserved coarse garnet porphyroblasts are pinkish, rich in inclusions of kyanite, white mica, quartz, apatite, zircon, and rutile. They display prograde compositional zonation, with decreasing almandine and increasing pyrope components. Almandine content varies from $84.2 \%$ to $58.03 \%$, whereas pyrope component range commonly from $7.32 \%$ in the core to $17 \%$ in the rim, reaching rarely $33.9 \%$. Grossular and spessartine components are low and usually with negligible variations. The outermost part of the rim sometimes shows reverse zoning with decreasing pyrope component and increasing spessartine or grossular ones, which we attribute to the cooling effect.
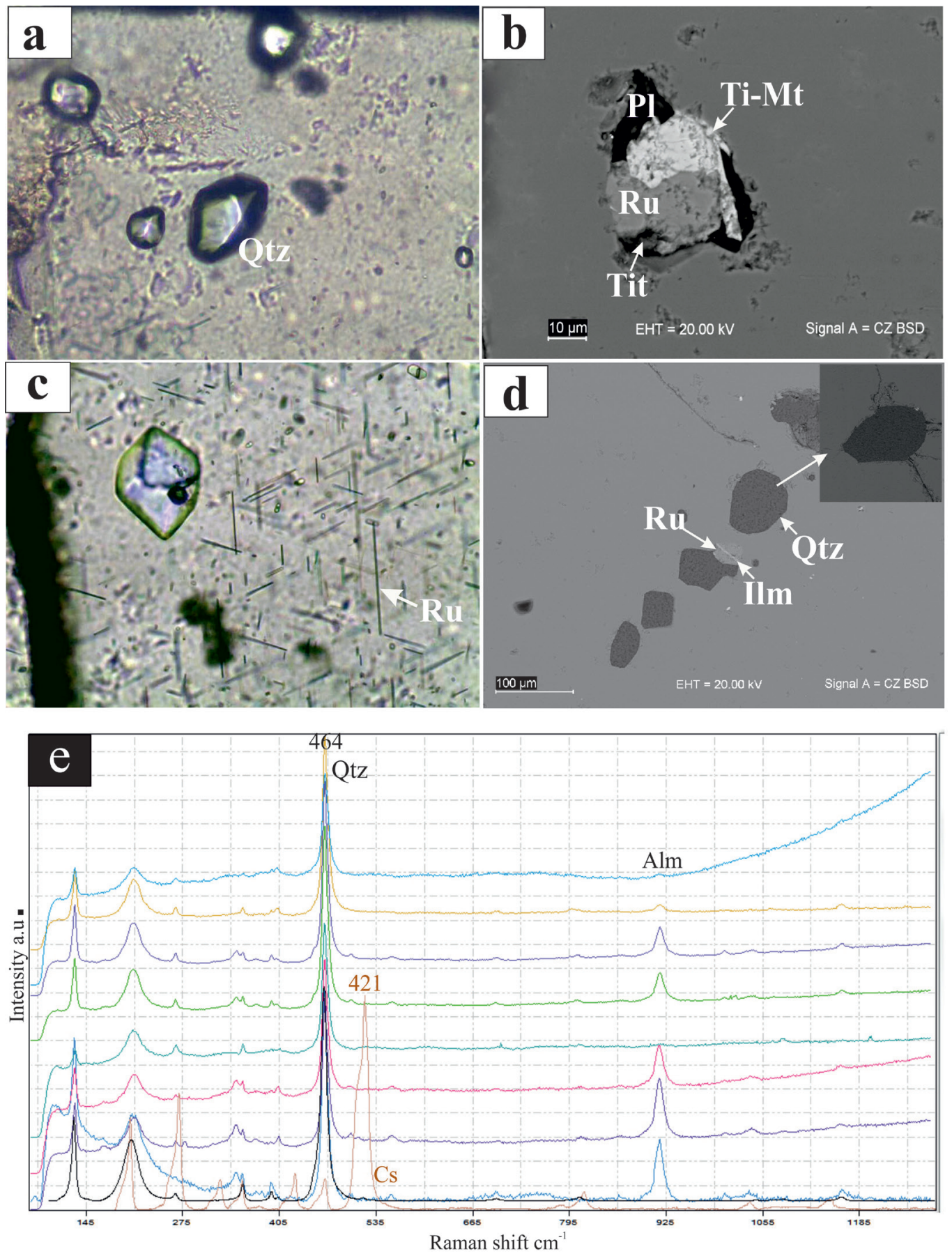

Fig. 1. Plane-polarized light photomicrograph $(a$ and $c$ ) and SEM imaged ( $b$ and $d$ ) of the microstructures of micro-inclusions; $e$, representative Raman spectra of monocrystaline euhedral quartz inclusions in garnet porphyroblasts. Due to the incomplete exposure of the grains on the surface garnet band at $917 \mathrm{~cm}^{-1}$ is visible, also. 


\section{Micro-inclusions in garnet porphyroblasts}

In addition to the already mentioned common inclusions in a coarse grained garnet porphyroblasts small (up to 50-100 $\mu \mathrm{m}$ ) inclusions are found, appearing dark-brownish under polarizing microscope which were impossible to be identifing. They are presented by different in shape and composition individuals, which have been studied by SEM and micro-Raman Spectroscopy. We would like to note that some of the inclusions detected with the polarizing microscope are not exposed on the surface, that's why it was impossible to analyze them.

Micro-inclusions are usually arranged in clusters, but single grains are found, too. Characteristic feature is the form of inclusions. It varies from irregular to well developed negative crystal shape and remarkable facetted outlines (Fig. 1a), which are parallel to rational crystallographic orientations of the host garnet. The negative crystal shape is attributed by Roedder (1984) to post-entrapment reequilibration of the system host-inclusion by process of dissolution-reprecepitation in order to be preserved the volume of the inclusion. The composition of the inclusions varies from multiphase to monomineralic quartz, rutile, apatite, glass inclusions.

Some of the observed inclusions are multiphase aggregates (Fig. 1b), composed of plagioclase, rutile, titanite, and titanomagnetite or represent white mica-potassium feldspar pair. We are aware that this is really not a minimum melt composition, which would allow us to call these inclusions true "Melt inclusions", but at present we didn't find inclusions with a granitic composition.

Another variety of micro-inclusion is glassy or fluid inclusion. We are not sure, because it is not fully exposed to the surface. However, it contains shrinkage bubble (Fig. 1c), which is a characteristic feature both for glassy and fluid inclusions, being formed according to Frezzotti (2001) during postentrapment cooling and crystallization.

We found many clusters of quartz micro-inclusions with well developed crystal faces (Fig.1d). Around some of them radiating fine cracks can be noticed through garnet host (Fig. 1d, insertation). This fact prompted us to study 10 of quartz microinclusions with micro-Raman spectroscopy. All grains show measured Raman spectra close to those of the $\alpha$-quartz standard with no shift and no splitting of the main quartz band at $464 \mathrm{~cm}^{-1}$ (Fig. 1e). Accordingly, we can reject the possibility these well facetted quartz grains to be former reequilibrated coesite grains. Nevertheless, Mposkos and Krohe (2006) suppose quartz with similar morphology from ultrahigh pressure metasediments of the Kimi Unit, East Rhodopes to be formed from a supercritical fluid entrapped into the growing garnet at ultrahigh-pressure conditions.

Additionally, we found 3 different types rutile inclusions in garnet: 1) rounded common rutile grains $(20-100 \mu \mathrm{m}$ in diameter) that do not show preferred growth orientation with respect to the garnet, 2) rutile grains (up to $20-30 \mu \mathrm{m}$ with well developed crystal faces, found with SEM and 3) rutile needles $(\sim 1 \mu \mathrm{m}$ wide, up to $100 \mu \mathrm{m}$ long) that show preferentially growth along the crustal faces of the host garnet. The last have been interpreted by most authors as exsolutions from a former titaniferous garnet. An interesting feature is that short prismatic apatite grains, comparable in size with rutile needles are found in clusters parallel to the crystallographic faces of the host garnet, too.

\section{Summary and conclusions}

Our investigations show that independently of the fact that we do not found typically polyphase melt inclusions with granitic composition, many of the described micro-inclusions can be formed by the presence of melt. This gives us some reason to assume that the studied micro-inclusions could be called "Melt inclusions", and the morphology of some of them suggests formation in rocks that have undergone high pressure metamorphism.

\section{References}

Burg, J.-P. 2012. Rhodope: from Mesozoic convergence to Cenozoic extension. Review of petro-structural data in the geochronological frame. - J. Virtual Explorer, 39, 44 p.

Frezzotti, M.-L. 2001. Silicate-melt inclusions in magmatic rocks: applications to petrology. - Lithos, 55, 273-299.

Mposkos, E, A. Krohe. 2006. Pressure-temperature-deformation paths of closely associated ultra-high-pressure (diamond bearing) crustal and mantle rocks of the Kimi complex: implications for the tectonic history of the Rhodope Mountains, northern Greece. - Can. J. Earth Sci. 43, 1755-1776.

Peytcheva, I., L. Macheva, A. von Quadt, N. Zidarov. 2015. Gondvana-derived units in Ograzhden and Belassitsa Mountains, Serbo-Macedonian Massif (SW Bulgaria): combined geochemical, petrological and U-Pb zircon-xenotime age constraints. - Geologica Balc., 44, 1-3, 51-84.

Ricou, L.-E., J.-P. Burg, I. Godfriaux, Z. Ivanov. 1998. Rhodope and Vardar: the metamorphic and the olistostromic paired belts related to the Cretaceous subduction under Europe. - Geodinamica Acta, 11, 6, 285-309.

Roedder, E. 1984. Fluid Inclusions. Review in Mineralogy, vol. 12. Washington, DC, Mineral. Soc. Am., 646 p.

Schmid, S. M., B. Fügenschuh, A. Kunov, L. Mațenco, P. Nievergelt, R. Oberhänsli, J. Pleuger, S. Schefer, R. Schuster, B. Tomljenović, K. Ustaszewski, D. van Hinsbergen. 2020. Tectonic units of the Alpine collision zone between Eastern Alps and western Turkey. - Gondwana Res., 78, 308-374. 